\title{
Ideje za reformu Izbornog zakonodavstva
}

\author{
Mirko Pejanović \\ Redovni član \\ Akademije nauka i umjetnosti Bosne i Hercegovine \\ pejanovicm@hotmail.com
}

\begin{abstract}
Sažetak: U referatu „Ideje za reformu izbornog zakonodavstva”, osim uvoda, obrađuju se ovi segmenti: društveno-istorijski uslovi u kojima se u Bosni i Hercegovini 1990. godine formira politički pluralizam na etničkoj osnovi, zatim oblikovanje zakonskog okvira za izborni sistem Bosne i Hercegovine u postdejtonskom razvoju Bosne i Hercegovine.

u elaboraciji teme, fokus je dat na ideje za reformu izbornog zakonodavstva. Pokrenute su sljedeće ideje: kako uvesti odredbu o vanrednim izborima, u svim situacijama, kad pobjedničke stranke odlažu više od šest mjeseci implementaciju rezultata parlamentarnih izbora.

Pokrenuta je i inicijativa da se podigne izborni cenzus za učešće stranaka u parlamentarnim izborima, tako što bi izborni cenzus umjesto $3 \%$ bio $5 \%$. Na ovaj način bi se okrupnjavala politička scena: u izborima bi učestvovao manji broj stranaka. Istovremeno bi pobjedničke stranke dobile veći koalicioni potencijal. Zagovara se i treća ideja za reformu izbornog zakonodavstva: uvođenje tehničkih inovacija u činu glasanja na izbornom mjestu.

Uzete u cjelini ideje koje se zagovaraju za reformu izbornog zakonodavstva anuliraju mnoge već pokrenute ideje, koje imaju za cilj da izborni sistem posluži daljoj etnizaciji prostora u Bosni i Hercegovini.
\end{abstract}

Ključne riječi: izborni sistemi, većinski izborni sistem, proporcijalni izborni sistem, izborni zakona Bosne i Hercegovine, vanredni izbori, Centralna izborna komisija, izborni cenzus

\section{Uvodni pristup}

Izborni sistem u demokratskoj državi predstavlja pravno-politički okvir unutar koga se provode aktivnosti u društvenom i političkom procesu izbora zastupnika-poslanika u parlamentarna predstavnička tijela. U savremenim državama liberalne demokratije izborni sistemi jesu suštinski dio funkcionisanja političkog sistema, jer legitimitet i moć Parlamenta kao nosioca ustavotvorne i zakonodavne vlasti stiče se u slobodnom i demokratskom ispoljavanju izborne volje građana. U tom kontekstu izborni sistem predstavlja način na koji glasači-nosioci izbornog prava svojim glasovima izražavaju preferencije u odnosu na stranke. 
Izborni sistem istovremeno ima dvostruku ulogu: on oblikuje stranački sistem i utiče na određivanje predstavništva. Tokom devetnaestog i dvadesetog stoljeća u evropskim demokratskim državama, izborno pravo je postalo neotuđivo političko pravo građana da biraju i da budu birani.

Zemlje Zapadnog svijeta u kojim je konsolidovan stranački sistem i učvršćena parlamentarna demokratija, imaju institucionalizirane izborne sisteme. Oni se javljaju kao većinski, zatim kao proporcionalni izborni sistemi. Zemlje koje su uvele većinske izborne sisteme u njima su se, dejstvom takvog izbornog sistema, oblikovali jaki dvostranački sistemi. Zapravo u strukturi stranaka većinski sistemi pokazuju tendenciju ka stvaranju dvostranačkih sistema. Radi se o sljedećim zemljama: Sjedinjene Američke Države, Engleska, Novi Zeland, Australija i Kanada. Sve ove zemlje, osim Sjedinjenih Američkih Država, imaju značajne i treće stranke koje dobijaju od deset do dvadeset posto glasova ${ }^{1}$. Istovremeno oni su najučestaliji institucionalni izborni sistemi. $\mathrm{U}$ institucionalne izborne sisteme ulazi i poluproporcijalni izborni sistem.

Tokom razvoja višestranačke demokratije u dvadesetom stoljeću u mnogim demokratskim državama, konsolidovan je stranački sistem u obliku snažnih stranaka desnice, centra i ljevice. Ovaj oblik stranačkog grupisanja prati društvene rascjepe koje uslovljavaju strukturne promjene u razvoju društva.

Krajem osamdesetih godina dvadesetog stoljeća nastaje društveni preokret $\mathrm{u}$ vezi sa egzistencijom jednopartijskih sistema u socijalističkim zemljama Evrope i svijeta. Nastaju istorijske promjene koje dolaze s padom Berlinskog zida 1989. godine, dolazi do sloma socijalističkog jednopartijskog uređenja u Sovjetskom savezu i istočnoevropskim socijalističkim zemljama. Taj val globalnih, istorijskih i društvenih promjena dovodi do ukidanja jednopartijskog sistema vladanja i u Jugoslovenskoj Socijalističkoj Federaciji. Disolucija Jugoslovenske Socijalističke Federacije dolazi do svoga kraja tokom 1990. i 1991. godine. Jugoslovenske Socijalističke republike tokom 1990-ih godina izvode političku pluralizaciju i organizuju prve višestranačke izbore. To su najprije uradile Slovenija i Hrvatska, dok su Makedonija i Bosna i Hercegovina političku pluralizaciju izvele sa izvjesnim zakašnjenjem u odnosu na Hrvatsku i Sloveniju.

${ }^{1}$ Vidi šire: Đovani Sartari: Uporedni ustavni inžinjering, „Filip Višnjič“, Beograd 2003, str. 56. i 57. 


\section{Društveno-istorijski uslovi u kojima se u Bosni i Hercegovini 1990. godine formira politički pluralizam na etničkoj osnovi}

Bosna i Hercegovina je kao i druge republike Jugoslovenske Socijalističke Federacije tokom 1990. godine ušla u istorijski proces političke pluralizacije. Skupština Republike Bosne i Hercegovine, kao najviši organ vlasti je u prvoj polovini 1990. godine usvojila zakonski okvir po kome su se mogle formirati političke stranke. Šire diskusije i javna rasprava obavljena je u okviru Ustavnog suda, o tome da li se stranke mogu formirati na etničkoj osnovi. Ustavni sud Bosne i Hercegovine je nakon rasprave donio odluku po kojoj građani imaju političko pravo da se udružuju i formiraju stranke na entičkoj osnovi. To je omogućilo da se od maja do avgusta 1990. godine formiraju tri jednoetničke stranke u Bosni i Hercegovini. Najprije je u mjesecu maju 1990. godine formirana Stranka demokratske akcije, kao stranka Bošnjačkog naroda. Potom je u julu mjesecu formirana Srpska demokratska stranka, kao stranka Srpskog naroda i Hrvatska demokratska zajednica Bosne i Hercegovine, kao stranka Hrvatskog naroda, formirano je u avgustu 1990. godine. Istovremeno su formirane i druge političke stranke kao demokratske, građanske i multietničke.

Opšta geopolitička kretanja u Evropi tokom 1990. godine kao i produbljivanje krize Jugoslovenske Socijalističke Federacije pretpostavljali su traženje rješenja za krizu Jugoslovenske Socijalističke Federacije. Razgovor o mogućim rješenjima vođeni su 1990. i 1991. godine na sastancima tadašnjih predsjednika predsjedništava Jugoslovenskih republika ${ }^{2}$. Stanovišta Jugoslovenskih republika o rješenju jugoslovenske krize bitno su se razlikovala. Oblikovana su tri osnovna koncepta: prvo ustroj Jugoslovenske Federacije s velikim ovlaštenjima; drugo: asimetrična federacija i treći koncept: suverenog i nezavisnog razvoja jugoslovenskih republika ${ }^{3}$. Prve projekte osamostaljenja od Jugoslovenske Federacije izvele su Slovenija i Hrvatska. Time je proces disolucije Socijalističke Federativne Republike Jugoslavije došao do svog kraja.

\footnotetext{
${ }^{2}$ Predsjednici predsjedništava u republikama bili su: Kiro Gligorov-Makedonija; Momir Bulatović-Crna Gora; Slobodan Milošević-Srbija; Alija Izetbegović-Bosna i Hercegovina; Franjo Tuđman-Hrvatska i Milan Kučan-Slovenija.

${ }^{3}$ Prvi koncept je zagovarao Slobodan Milošević, predsjednik predsjedništva Srbije. Drugi koncept su zagovarali Kiro Gligrski i Alija Izetbegović, predsjednici predsjedništva Makedonije i Bosne i Hercegovine. Treći koncept je suveren i nezavisan razvoj republika, je zagovaran od Hrvatske i Slovenije i drugih republika.
} 
Strah od pogoršanja sigurnosti uslijed raspada Federativne Jugoslavije kod građana u Bosni i Hercegovini je doveo do etničke homogenizacije. Na toj osnovi su tokom 1990. godine inicijativni odbori za formiranje nacionalnih stranaka dobili podršku pripadnika jednog, drugog ili trećeg etničkog korpusa u Bosni i Hercegovini: Srpskog, Hrvatskog, Bošnjačkog. Kad su nacionalne stranke započele izbornu kampanju u avgustu i septembru 1990. godine, one su se proglasile kao ekskluzivni zastupnici nacionalnih interesa svojih naroda (podvukao M.P.). Zapravo, Stranka demokratske akcije je programski oblikovala nacionalne interese Bošnjaka, Srpska demokratska stranka interese Srba i Hrvatska demokratska zajednica Bosne i Hercegovine nacionalne interese Hrvata. Tako je nacionalna pripadnost postala istovremeno i politička pripadnost. Tri nacionalne stranke su kao svojevrsni pokreti pridobile podršku pripadnika svojih etničkih skupina. Osim toga, nacionalne stranke HDZBiH, SDS i SDA su tokom izborne kampanje u septembru i oktobru dobile medijsku podršku i podršku brojnih nevladinih organizacija iz zapadnoevropskih zemalja.

Istovremeno odvijanje etničke homogenizacije, u obliku grupisanja unutar tri nacionalne stranke dovelo je do apsolutne izborne pobjede: SDA, HDZBiH i SDA na prvim višestranačkim izborima u Bosni i Hercegovini, 19. novembra 1990. godine.

Tri etničke stranke : HDZBiH, SDS i SDA su na prvim višestranačkim izborima 1990. godine, zajedno osvojile 84\% mandata u Skupštini Republike Bosne i Hercegovine. Sve druge multietničke i građanske stranke osvojile su $16 \%$ povjerenja izbornog tijela u Bosni i Hercegovini. ${ }^{4}$ Ovim su nacionalne stranke učvrstile političko organizovanje na etničkoj osnovi. Svi relevantni društveni interesi ispoljavali su se i oblikovali na etničkoj osnovi. Prva višestranačka vlada na početku 1991. godine i sva ministarstva dogovorno su podijeljena između tri etničke stranke. Međutim, istovremeno, tri etničke stranke nisu oblikovale, niti usvojile koalicioni sporazum o formiranju parlamentarne većine, odnosno vlade parlamentarne većine. Zapravo, izbjeglo se definisanje programskih osnova na kojima će se donositi zakoni i drugi akti. Odlučeno je da se upravlja Bosnom i Hercegovinom na partnerskim odnosima vladajućih stranaka(podvukao M.P.). Budući da su među vladajućim strankama postojale razlike u stajalištima prema razvoju državnosti Bosne i Hercegovine i njene budućnosti, prvo neslaganje, a potom i konflikt između

\footnotetext{
${ }^{4}$ Vidi šire: Mirko Pejanović: Struktura i karakteristike razvoja političkog pluralizma u Bosni i Hercegovini, u: Pluralizam u Sloveniji i Bosni i Hercegovini, urednici Danica Fink Hafner, Mirko Pejanović, Sarajevo/Ljubljana, Promocult, Fakultet političkih nauka, Sarajevo, 2006, str. 81-104.
} 
vladajućih stranaka javio se u drugoj polovini 1991. godine. Neslaganje se ispoljilo u diskusiji o državnosti Republike Bosne i Hercegovine, unutar već dovršene disolucije SFRJ. Dvije nacionalne stranke: HDZ i SDA, zajedno s pet opozicionih stranaka, zagovarale su koncept suverenog i nezavisnog državno-pravnog razvoja Bosne i Hercegovine u budućnosti (podvukao M.P.). Bosna i Hercegovina je, kao jedna od šest ravnopravnih republika, imala istorijsko pravo da oblikuje svoj državno-pravni status, kao što su to uradile Slovenija, Hrvatska i Makedonija. Ovom konceptu je bilo suprotstavljeno stanovište Srpske demokratske stranke kao jedne od vladajućih stranaka. Srpska demokratska stranka kojom je rukovodio Radovan Karadžić je otvoreno zagovarala političko stajalište da je Bosna i Hercegovina samo jedna administrativna tvorevina. Ona ne može imati pravo na suvereno-državni pravni status izvan Jugoslavije. Suverenost Bosne i Hercegovine prema stajalištu Srpske demokratske stranke „mora biti ograničena i vezana za Jugoslaviju“. 5 Rješenje za neslaganje vladajućih stranaka pronađeno je u oblikovanju ideje i donošenju odluke Parlamenta Bosne i Hercegovine, 25. februara o raspisivanju Republičkog referenduma građana. Referendum je održan 29. februara i 1. marta 1992. godine. Izlaskom građana u postotku od 64\% na referendum i glasanjem sa $99 \%$ za suvereni i nezavisni državno-pravni status Bosne i Hercegovine iskazana je demokratska volja građana Bosne i Hercegovine da njihova domovina i država Bosna i Hercegovina, na temelju dotadašnjeg istorijskog razvoja, ima pravo egzistirati i razvijati se kao nezavisna i suverena država unutar evropskih država i naroda (podvukao M.P.).

Na temelju rezultata referenduma građana, Bosna i Hercegovina je u aprilu mjesecu 1992. godine dobila međunarodno priznanje. Njen miran razvoj zaustavila je vojna agresija Miloševićevog režima i Jugoslovenske narodne armije. Rat je trajao do Dejtonskog mirovnog sporazuma 1995. godine. Odbranu Bosne i Hercegovine i pregovore o miru u Bosni i Hercegovini vodilo je ratno multietničko Predsjedništvo Republike Bosne i Hercegovine.

U okviru Dejtonskog mirovnog sporazuma Bosna i Hercegovina je dobila novi-Dejtonski ustav. Po ovom ustavu Bosna i Hercegovina je država sa svojim teritorijalnim integretitetom i unutrašnjim ustrojstvom: dva entiteta i Distriktom Brčko. Tako je Bosna i Hercegovina dobila entitetsko-etničko ustrojstvo državne Bosne i Hercegovine. To ustrojstvo je omogućilo dominaciju ispoljavanja društvene interesa na etničkoj osnovi. Zbog toga, Bosna i

\footnotetext{
${ }^{5}$ Vidi šire: Mirko Pejanović: struktura i karakteristike razvoja političkog pluralizma u Bosni i Hercegovini 1989-2003, u: Ogledi o državnosti i političkom razvoju Bosne i Hercegovine, treće dopunjeno izdanje, Šahinpašić, Sarajevo, 2013, str. 90 i 91.
} 
Hercegovina u postdejtonskom vremenu, egzistira kao nefunkcionalna država (podvukao M.P.).

\section{Oblikovanje zakonskog okvira za izborni sistem Bosne i Hercegovine u postdejtonskom razvoju Bosne i Hercegovine}

Prvi, drugi i treći poslijeratni Parlamentarni izbori, nakon potpisivanja Dejtonskog mirovnog sporazuma, održani su 1996, 1998. i 2000. godine. Tada su parlamentarni mandati trajali po dvije godine.

Ova tri izborna ciklusa, organizovala je i provodila Međunarodna zajednica, zapravo OSCE, kao dio Međunarodne zajednice u Bosni i Hercegovini. Uslijedila je i promjena dužine trajanja mandata parlamenata od 2002. godine. Od tada, mandati parlamenata traju četiri godine.

Tokom 2001. godine, usvojen je Izborni zakon Bosne i Hercegovine ${ }^{6}$. Njegovim usvajanjem formirana je izborna administracija i njena glavna institucija: Centralna izborna komisija. Formirane su i opštinske izborne komisije i glasački odbori. Bosna i Hercegovina samostalno organizuje i provodi parlamentarne izbore od 2002. godine. Prema rezultatima izbora, građani su u postdejtonskom periodu, samo u dva izborna ciklusa dali većinsko povjerenje građanskim, multietničkim strankama: 2000. i 2010. godine. Na šest izbornih ciklusa: 1996, 1998, 2002, 2006, 2014. i 2018. godine građani su dali većinsko izborno povjerenje nacionalnim strankama: Stranci demokratske akcije, Srpskoj demokratskoj stranci i Hrvatskoj demokratskoj zajednici, s tim što od 2006. godine Srpsku demokratsku stranku potiskuje i zamjenjuje Savez nezavisnih socijaldemokrata.

U teorijskim analizama i empirijskim istraživanjima postoji saglasnost da etničke stranke u Bosni i Hercegovine dobijaju većinsko povjerenje građana, uslijed širenja straha na etničkim suprotnostima (podvukao M.P.). Tako se izborno tijelo Bosne i Hercegovine tokom izbornih procesa, javlja u obliku tronacionalne podjele na srpsko, hrvatsko i bošnjačko izborno tijelo. Cjelina izbornog tijela-demosa Bosne i Hercegovine se fragmentira u tri odvojene potcjeline. Tome, svakako doprinosi dvoentitetska teritorijalna struktura države na etničkoj osnovi i fragmentirani stranački sistem. Na prvim parlamentarnim izborima 1990. godine učestvovalo je 15 političkih stranaka da bi broj stranaka koje učestvuju na izborima 2018. godine narastao na 69.

\footnotetext{
${ }^{6}$ Zakon je objavljen u Službenom glasniku Bosne i Hercegovine br. 23 od 2001. godine. U protekle dvije decenije izvršeno je 19 intervencija na Zakon u smislu izmjena i dopuna. Posljednje izmjene su bile 2016. godine.
} 
Ojačao se i učvrstio politički pluralizam na etničkoj osnovi. Izbornu pobjedu dobijaju Stranka demokratske akcije, Hrvatska demokratska zajednica Bosne i Hercegovine i Savez nezavisnih socijaldemokrata Milorada Dodika. Ove tri stranke su izbornu pobjedu dobile i 2014. i 2018. godine. Nakon provedenih parlamentarnih izbora, ove pobjedničke stranke vršenje vlasti zasnivaju na partnerskim odnosima (podvukao M.P.). Rade to tako, jer, nemaju koalicioni o parlamentarnoj većini. Slože se samo o podjeli resora u državnim ministarstvima. Konsenzus, u obliku koalicionog sporazuma za formiranje parlamentarne većine, ne uspijevaju izgraditi (podvukao M.P.). Radi se o tome da postoje bitne razlike u političkim stajalištima stranaka o socijalnoekonomskom, kulturnom i političkom razvoju države Bosne i Hercegovine. Tako, naprimjer Savez nezavisnih socijaldemokrata negira državu Bosnu i Hercegovinu i vrlo često blokira rad institucija države Bosne i Hercegovine. Na drugoj strani Hrvatska demokratska zajednica svojim isključivim zahtjevima osporava više od dvije godine konstituisanje Vlade Federacije Bosne i Hercegovine nakon parlamentarnih izbora 2018. godine.

Nakon parlamentarnih izbora 2018. godine, više od godinu dana je prošlo do izbora Vijeća ministarstva. U Federaciji Bosne i Hercegovine je od 2018. godine do 2021. godine prošlo dvije godine, a nije došlo do implementacije izbornih rezultata nakon parlamentarnih izbora 2018. godine.

Centralna izborna komisija, prema sadašnjem izbornom zakonu Bosne i Hercegovine nema ovlaštenja da donese odluku o provođenju vanrednih izbora. Zapravo ne postoji zakonski rok do koga se implementiraju rezultati izbora. Ne postoji ni zakonska odredba u izbornom zakonu na temelju koje, nakon isteka roka od šest mjeseci za konstituisanje vlasti, centralna izborna komisija donosi odluku o provođenju vanrednih izbora. Izbjegavanje konstituisanja vlasti u predviđenom roku, nakon provedenih izbora, postaje ustaljena praksa. To govori o političkoj neodgovornosti stranaka i zanemarivanju interesa građana. Ovim se negira i princip smjenjivosti organa vlasti putem demokratskih izbora.

Postojeća praznina u izbornom zakonu sprečava Centralnu izbornu komisiju da provodi vanredne izbore, u svim situacijama, kad birokratizovani i otuđeni vrhovi stranaka, ne uspijevaju provesti rezultate parlamentarnih izbora (podvukao M.P.). Eklantan primjer za neprovođenje rezultata parlamentarnih izbora je izbjegavanje konstituisanje vlasti u Federaciji Bosne i Hercegovine više od dvije godine poslije provedenih parlamentarnih izbora 2018. godine. Na ovaj način se negira parlamentarna demokratija i uvodi monopol stranačkih elita da upravljaju razvojem društva. Parlamentarna 
demokratija se zamjenjuje partitokratijom (podvukao M.P.). Ovo je postao jedan od najvećih problema u izbornom sistemu Bosne i Hercegovine. Drugi veliki problem izbornog sistema proističe iz atomiziranosti stranačkog sistema. Konsolidacija stranačkog sistema, u pravcu okrupnjavanja stranaka na na političkoj areni, nije moguća bez uvođenja novog zakonskog cenzusa koji bi bio veći od sadašnjeg 3\% udjela jedne stranke u izbornom tijelu.

\section{Ideje za reformu izbornog zakonodavstva}

Postojeći izborni zakon u Bosni i Hercegovini moguće je mijenjati, a da se ne zahtijeva promjena Ustava Bose i Hercegovine. Radi se o promjenama Izbornog zakona Bosne i Hercegovine koje mogu osigurati novu stabilnost stranačkog sistema u Bosni i Hercegovini.

Nekoliko ideja imaju primat u vršenju promjena izbornog zakona Bosne i Hercegovine.

Kao prva ideja javlja se nužnost ugradnje odredbe u izbornom zakonu o vanrednim izborima. To podrazumijeva da se u zakonu ograniči vrijeme na šest mjeseci u kome se vrši implementacija izbora. Kad pobjedničke stranke ne formiraju vlast u predviđenom zakonskom roku slijedi raspisivanje vanrednih izbora. Odredba za provođenje vanrednih izbora i u entitetima i u državi Bosni i Hercegovini daje ovlaštenje Centralnoj izbornoj komisiji da donese odluku o raspisivanju vanrednih izbora. Ovakva zakonska odredba će ukinuti monopol i neodgovornost stranaka da izbjegavaju provesti izborne rezultate. Osim toga ova zakonska odredba će dovesti do konsolidacije stranačkog sistema. Otpadaće stranke koje ne mogu ili neće da grade koalicione sporazume o formiranju parlamentarne većine.

Druga ideja za promjenu izbornog zakona odnosi se na uvođenje novog cenzusa za učešće političkih stranaka u izborima. U većini zapadnoevropskih demokratskih država izborni cenzus za učešće stranaka u parlamentarnim izborima iznosi 5\%. Republika Turska ima izborni cenzus s 10\%. Bosna i Hercegovina je tranzicijska i postsocijalistička zemlja. U cilju konsolidacije demokratije i stranačkog sistema, izborni cenzus treba podići sa 3\% na 5\% učešća stranke u izbornom tijelu. To bi pomoglo da stranački sistem ne bude ovoliko atomiziran.

U cilju transparentnosti izbornog procesa, nevladine organizacije koje vrše monitoring izbora predlažu uvođenje tehničkih inovacija na glasačkim mjestima. Skeniranje glasačkog listića spriječilo bi moguće zloupotrebe i izborne volje građana. 
Kad su u pitanju izbori za opštinska vijeća, odnosno skupštine i gradska vijeća i gradske skupština javlja se jedno pitanje o tome kako ojačati građanski interesni pluralizam. Zapravo radi se o ideji da se izmijeni struktura izbornih jedinica. Umjesto teritorije opštine kao jedne izborne jedinice za opštinsko vijeće, uvelo bi se više izbornih jedinica za izbor opštinskih vijećnika. Teritorijalna osnova za izbornu jedinicu bile bi jedna ili više mjesnih zajednica (podvukao M.P.). Na ovaj način bi građani imali mogućnost veće identifikacije s kandidatima za vijećnike u njihovoj mjesnoj zajednici. Istovremeno bi bila i veća mogućnost kontrole građana nad radom vijećnika, posebno u odlučivanju o opštinskom budžetu i kapitalnim investicijama u izgradnji komunalne infrastrukture u jedinici lokalne samouprave.

S ovim promjenama izbornog zakona Bosne i Hercegovine izborni sistem bi postao povoljniji okvir za ispoljavanje izborne volje građana i postizanja novih dosega u razvoju izborne demokratije.

\section{Zaključak}

Bosna i Hercegovine je u procesu disolucije Jugoslovenske Socijalističke Federacije krajem 80-ih godina i početkom 90-ih godina dvadesetog stoljeća izvela istorijski pokret pluralizacije bosanskohercegovačkog društva i imala prve višestranačke izbore. Tokom 1991. godine višestranačka skupština Bosne i Hercegovine je odlučivala o državno-pravnom statusu Bosne i Hercegovine u budućnosti. Parlament Bosne i Hercegovine je 25. januara 1992. godine donio odluku o raspisivanju Republičkog referenduma građana za izjašnjavanje o suverenom i nezavisnom statusu Bosne i Hercegovine. Voljom građana, a na referendum je izašlo $64 \%$ građana upisanih u birački spisak, je odlučeno da Bosna i Hercegovina, kao i druge jugoslovenske republike dobije državnopravni status suverene i nezavisne države. Na temelju rezultata referenduma, Bosna i Hercegovina je 6. aprila 1992. godine dobila međunarodno priznanje, a i postala članica organizacije Ujedinjenih nacija. Nakon toga Bosna i Hercegovina nije imala istorijsku sreću da u miru izvodi postsocijalističku tranziciju. Uslijedio je rat koji je zaustavljen Dejtonskim mirovnim sporazumom u novembru mjesecu 1995. godine.

U okviru Dejtonskog mirovnog sporazuma Bosna i Hercegovina je dobila ustav i novo ustavno-političko ustrojstvo. Prema Dejtonskom ustavu Bosna i Hercegovina nastavlja svoj državno-pravni kontinuitet (podvukao M.P.) sa institucijama države i dva entiteta. Entiteti su zasnovani na etničkoj osnovi. Zbog toga se ispoljavanje svih društvenih interesa dominantno odvija na 
etničkoj osnovi. Radi se o tome da je dominacija etničkog momenta u unutrašnjem ustrojstvu Bosne i Hercegovine dovela do učvršćivanja etničkog pluralizma u političkoj sferi (podvukao M.P.).

U postdejtonskom periodu, uz angažovanje Međunarodne zajednice, započela je demokratska konsolidacija i izgradnja državnih institucija. Parlamentarne izbore proveo je OSCE 1996. i 1998. godine. Nakon toga je 2000. godine donesen izborni zakon Bosne i Hercegovine, čime je pravno utemeljen izborni sistem Bosne i Hercegovine. Ovim je omogućeno formiranje Centralne izborne komisije i opštinskih izbornih komisija što je označilo uspostavu izborne administracije.

Tokom dvije decenije postdejtonskog političkog razvoju u Bosni i Hercegovini je provedeno: osam parlamentarnih izbora: 1996, 1998, 2000, 2002, 2006, 2010, 2014. i 2018. godine. Svi parlamentarni izbori su provedeni mirno, što znači da se odvijao demokratski proces smjenjivosti parlamenata i vlada.

Kao glavni problem u funkcionisanju izbornog sistema javlja se u nedostatku zakonske odredbe za provođenje vanrednih izbora u slučajevima kada pobjedničke stranke u očekivanom roku, a to je šest mjeseci, ne implementiraju izborne rezultate. Taj problem se posebno ispoljio nakon parlamentarnih izbora 2018. godine. Državna vlada je izabrana sa godinu i više zakašnjenja. Istovremeno, nova Vlada Federacije Bosne i Hercegovine nije izabrana od 2018. do 2021. godine. Čak ne postoje naznake da bi se Vlada Federacije Bosne i Hercegovine mogla formirati do kraja tekućeg mandata, a to znači do parlamentarnih izbora 2022. godine.

Među idejama za reformu izbornog zakonodavstva predlažu se ove ideje:

- Prvo uvođenje zakonske odredbe o vanrednim izborima kad političke stranke prave opstrukciju za implementaciju rezultata parlamentarnih izbora, u zakonom propisanom vremenu.

- Drugo, ideja se odnosi na povećanje izbornog cenzusa za učešće stranaka na parlamentarnim izborima sa 3\% na 5\%. To bi doprinijelo smanjenju postojeće atomiziranosti političkog pluralizma. Pobjedničke stranke bi uspješnije uspostavljale koalicije za vršenje vlasti nakon izbora.

- Treća ideja za reformu izbornog zakonodavstva odnosi se na tehničke inovacije na glasačkim mjestima kako bi izborni proces bio u potpunosti transparentan.

Zagovara se i četvrta ideja, a to je kreacije nove strukture izbornih jedinica za izbor opštinskih i gradskih vijećnika, odnosno odbornika u opštinama i gradovima, tako što bi izborne jedinice činile jedno ili više mjesnih zajednica. 


\section{Literatura}

Dr. Suad Arnautović: Kontroverze o izborima i izbornom sistemu Bosne i Hercegovine, Promocult, Sarajevo 2017.

Đovani Sartori: Uporedni ustavni inženjering, Filip Višnjić, Beograd 2003.

Dr. Ahmet Šantić: Izborno pravo-iskustvo Bosne i Hercegovine i evropskih država, University Press-Izdanje magistrat, Sarajevo 2014.

Kvint Tulije Ciceron: Izborni priručnik sa govorima Marka Tulija Cicerona, University Press, Izdanje magistrat, Sarajevo 2018.

Mirko Pejanović: Ogledi o državnosti i političkom razvoju Bosne i Hercegovine, Treće dopunjeno izdanje, Šahinpašić, Sarajevo 2013.

Mirko Pejanović: Država Bosna i Hercegovina i demokratija, University Press, Izdanje magistrat, Sarajevo 2015.

Antonio Pehar: Ustavna demokracija za Bosnu i Hercegovinu, Čigoja, Beograd 2012.

Danica Fink Hafner-Mirko Pejanović: Razvoj političkog pluralizma u Sloveniji i Bosni i Hecegovini, Promocult, Sarajevo/Ljubljana 2006.

Slaviša Orlović: Politička sociologija, Univerzitet u Beogradu, Fakultet političkih nauka, Beograd 2019.

Mr. Hilmo Pašić: Izbori u Bosni i Hercegovini 2002. godine, Centar za promociju civilnog društva 2004.

Bosna i Hercegovina-15 godina Dejtonskog mirovnog sporazuma, Međunarodni simpozij, zbornik radova, Univerzitet u Sarajevu, Sarajevo 2011.

Izborni zakon Bosne i Hercegovine, Službeni glasnik Bosne i Hercegovine br. 23 od 2001. godine.

\section{Ideas for the Reform of Electoral Legislation}

\section{Summary}

In this paper "Ideas for the Reform of Electoral Legislation", apart an introduction, following segments are explored: social and historical conditions in which political pluralisms upon ethnic basis is formed in Bosnia and Herzegovina in 1990, then, creation of legal frame regarding electoral system of Bosnia and Herzegovina in post Dayton development of Bosnia and Herzegovina. In topic's elaboration, focus is situated on ideas for the reform of electoral legislation. Following ideas are presented: how to impose the regulation on a by- elections, in all numerous situations, when winning political parties delay an implementation of parliamentary elections more than six months. There is also an initiative for electoral census to be raised for the participation of political parties in parliamentarian elections, instead of 3\% for the electoral census to be $5 \%$. This is the way to create an enlargement of the political scene: a smaller number of political parties would participate in elections. At the same time, winning political parties would gain larger coalition potential. Additionally, there is the third idea for the reform of electoral legislation: introduction of technical innovations regarding the act of voting at the electoral places. Taken in general manner, these ideas for the reform 
Posebna izdanja ANUBiH CXCVIII, ODN knjiga 17

of electoral legislation annul many already ongoing ideas that are aimed to further ethnize Bosnia and Herzegovina using an electoral system to do so.

Key words: electoral systems, majority electoral system, proportional electoral system, electoral legislation of Bosnia and Herzegovina, by-elections, Central Election Commission, electoral census 